\title{
Influencing Factors and Mechanism of Coal Enterprise Merger and Acquisition from the Perspective of Dynamic Capability
}

\author{
Zhen Zhou*, Min Zhou \\ School of Economics and Management, China University of Mining and Technology, Xuzhou, Jiangsu \\ Province, China \\ *Corresponding Author.
}

\begin{abstract}
Merger and acquisition $(M \& A)$ is an important way for coal enterprises to acquire key competitive resources and core competencies and achieve rapid growth. In the existing research, more emphasis is placed on integration policies, methods and performance evaluation, lack of theoretical analysis and empirical testing on the key decision-making factors and driving mechanism of coal enterprises' M\&A. In this paper, a conceptual model of influencing factors and action mechanism of coal enterprise $M \& A$ is constructed, and the relationship between influencing factors, ability construction and enterprise performance of coal enterprise $M \& A$ is discussed from the perspective of dynamic ability. Based on 323 sample data of coal enterprises in key coal-producing areas in China, the research hypothesis is empirically tested by hierarchical regression and structural equation model. The research reveals that government regulation, industry competition, entrepreneurial orientation and organizational alertness have significant positive effects on coal enterprise M\&A. Government regulation and industry competition have a positive impact on environmental perception and resource reconfiguration, but an insignificantly positive impact on resource integration, which also verifies the negative effect between government regulation and industry competition.
\end{abstract}

Keywords: coal enterprise merger and acquisition (M\&A); influencing factors; mechanism of action; dynamic capability

\section{I.Introduction}

Coal is the main energy source in China, which is of great strategic significance to ensure national energy security.In recent years, China has continuously strengthened the regulation and control of the coal industry by promoting mergers and acquisitions (M\&A) of coal enterprises, building large coal enterprise groups and improving industrial concentration.At the macro level, the state has issued several opinions on accelerating the merger, reorganization, transformation and upgrading of coal enterprises, and promoted the withdrawal of of excess and backward production capacity and industry progress through the merger and reorganization.At the micro level, M\&A between large coal enterprises and local small coal enterprises are surging, and a number of giant coal enterprises such as China Energy, Shandong Energy and Jinneng Group have been set up one after another.M\&A has become an important strategy for coal enterprises to acquire key resources and core capabilities, achieve rapid growth and build competitive advantages [1], which has become a common phenomenon in the coal enterprise industry.On the one hand, the coal industry has expanded its scale and restructured the industry competition order through horizontal integration, and extended the enterprise value chain through vertical merger and acquisition, which has significantly improved the overall quality [2]. On the other hand, the deep-seated problems in the development of the coal industry do not appear to be solved [3].The coal industry is still in a painful period of replacing old growth drivers with new ones, with a large number of enterprises still suffering from resource-based losses, geographical losses, policy and regulatory losses and operating losses. A large number of M\&A, especially regional M\&A, are unfinished and face the risk of failure [4, 5].

There is still a theoretical gap in existing research on M\&A of coal enterprises [6-10].First of all, in the existing research, more attention is paid to government policies, integration methods, integration performance evaluation and other topics, relatively few for coal enterprise integration motivation as a whole, especially for the economic

ISSN: 0010-8189

(C) CONVERTER 2021

www.converter-magazine.info 
system, government regulation, industrial characteristics, competitive strength, network relations, organizational cognition, group characteristics, individual characteristics and other internal and external integration motivation research, with scarce empirical research. Secondly, the key elements and driving mechanism of coal enterprises' M\&A decision are still unclear, and the relevant theoretical framework has not yet been established.Third, the research on the performance of coal enterprises M\&A integration is contradictory, which needs further empirical verification.Fourthly, most of the existing researches study the M\&A performance and M\&A value of coal enterprises through synergy theory and core competence theory, which to some extent ignores the impact of the core rigidity of competence and the dynamic and complexity of the rapidly changing external environment on M\&A performance.Fifthly, the concepts of M\&A motivation, capability building, resource integration, resource reconfiguration and enterprise performance are not included in the overall research framework to explore the relationship between them.

In this study, from the perspective of capacity building, a theoretical analysis model of influencing factors and mechanism of M\&A is established by studying the influencing factors and mechanism of M\&A of coal enterprises to explain the surging M\&A phenomenon of coal enterprises.It is believed that M\&A is a complex entrepreneurial behavior of enterprises and an important form of change decision and organizational change of coal enterprises, which is affected by the interaction and multiple feedbacks of external environmental factors, internal organizational factors, cognitive factors and action factors of enterprises.In China's coal industry, state-owned enterprises are the main body, and the government is an important external force to promote the implementation of mergers and acquisitions of coal enterprises. The government regulation has a profound impact on the resource integration and resource reconfiguration of coal enterprises [11].Due to the fragility of coal industry, such as low industrial concentration, high competition intensity and periodic fluctuation, entrepreneurship orientation, organizational alertness and industry competition have become important motivations for coal enterprises to implement M\&A.Entrepreneurship-oriented reflects the coal enterprises' active pursuit of market opportunities, the implementation of innovation in technology and organization, and taking risky actions, which affects the environmental perception, resource integration and resource reconfiguration of coal enterprises[12].Organizational alertness is the premise for enterprises to implement competitive behavior, which can enhance organizational adaptability and prompt coal enterprises to make major change decisions such as M\&A.Industry competition forces coal enterprises to solve the homogenization problem through resource reconfiguration, and then shape the core competitiveness.In order to verify the above theoretical logic, in this paper, firstly, 323 sample data of coal enterprises in key coal-producing areas in China were collected by questionnaire, and then the research hypothesis was empirically analyzed by using hierarchical regression analysis and structural equation model. Next, from the perspective of dynamic capability, the relationship between influencing factors, capacity building and enterprise performance of coal enterprises was discussed, and the relationship model of influencing factors and action mechanism of coal enterprises' mergers and acquisitions was constructed.

\section{Literature Review and Research Hypotheses}

In the existing literature [13-16], the research on the motivation of enterprise merger and acquisition can be divided into three arguments, namely, efficiency theory, hubris hypothesis and agency theory.In most studies, attention has been paid to the fact that mergers and acquisitions can quickly diversify, seize new opportunities, enter new markets, strengthen economies of scale and scope, quickly enrich product lines, achieve intensive cultivation of existing markets, defeat competitors, quickly extend industrial chains, acquire valuable technologies, enter international markets with low risks, and restructure low-performance enterprises, etc. In addition, studies have also been made on when mergers and acquisitions will take place, their performance after mergers and acquisitions, and the reasons why some mergers and acquisitions are more successful from the perspectives of learning, systems, principal-agent and moral hazard of managers, etc.As for the coal industry, most of the existing literature focuses on government integration policies, integration methods, specific issues in the integration process (the issue of "the state sector advancing while the private sector is retreating", financial issues, integration interface, etc.), integration performance evaluation (index system construction, evaluation method discussion), etc.

ISSN: 0010-8189

(C) CONVERTER 2021

www.converter-magazine.info 
M\&A of coal enterprises has its own special attributes [17].Firstly, the coal industry has unreasonable structure, low industrial concentration, obvious cyclical fluctuation, fierce competition and obvious vulnerability of coal enterprises.Secondly, the current survival and development of coal enterprises mainly depend on the reserves and conditions of coal resources, and resource elements make the greatest contribution to the development of coal enterprises.Third, the core competitive elements of coal enterprises are mainly controlled by governments at all levels, and the influence of government forces on the survival and development of coal enterprises is much greater than that of market forces. The government, which controls a variety of important strategic resources and has a great power of project approval and resource distribution, will actively intervene in the decision-making of coal enterprises' operation and management by using its own power in pursuit of multiple social goals such as economic development, employment or social stability, which will have great influence or decision-making power on the choice of coal enterprises' growth strategy, and will also promote the merger and acquisition integration of coal enterprises through strict industrial control. As a result, coal enterprises must be alert at all times, pay attention to the changes in government regulatory policies, and take countermeasures to adapt to the external requirements of the government.Fourth, the fragility of the industry leads to a strong sense of crisis in coal enterprises. Although the development environment of the coal industry has been improved and the market competition order has been standardized after many years of reform and development, the industry is facing serious homogeneous competition, with a large number of enterprises suffering from resource-based losses, geographical losses, policy and regulatory losses and operating losses. According to the view of environmental decision, the industry conditions determine the strategic decisions of enterprises, and enterprises should adopt different strategies to cope with the changes of industry conditions. Therefore, it is a common choice for coal enterprises to cope with the industry competition to realize extensive expansion through mergers and acquisitions.Fifth, in order to survive and develop, coal enterprises must abandon their traditional concept of development, establish a new concept of entrepreneurship, continue to carry out entrepreneurial and innovative activities, and constantly create new undertakings and enter new fields to enhance their ability to survive and develop. Under the background of transition economy, the concept and behavior of entrepreneurship and innovation are of great significance to improve the competitiveness and organizational performance of coal enterprises.Sixth, in the realistic situation, M\&A behavior is divided into four stages: pre-preparation, M\&A design, negotiation and signing, and post-M\&A integration. Whether M\&A opportunities and resources can be identified, and whether resources can be integrated and reconstructed are the key factors to achieve M\&A performance. In terms of the factors that influence the success of M\&A, many researches focus on the factors that build the enterprise capability through M\&A [18-20].As a high-level organizational capability, dynamic capability includes the perception of external opportunities and threats, the integration of internal and external resources and skills, and the separation and reconstruction of resources, which are consistent with the key process connotation of $\mathrm{M} \& \mathrm{~A}$. M\&A is the entrepreneurial process within an enterprise organization, and successful M\&A is the process of building dynamic capability of an enterprise.A large number of studies have shown that M\&A can quickly acquire dynamic capabilities, and then affect enterprise performance.

Based on the above analysis, in this paper, the process of M\&A integration of coal enterprises is regarded as the process of dynamic capability building, and two external factors, namely, government regulation and industry competition, and two internal factors, namely, organizational alertness and entrepreneurship orientation, as well as enterprise performance are included in the analysis framework, and the relationship between them is tested and discussed under the background of coal enterprises.

\subsection{Government regulation and M\&A integration of coal enterprises}

Government regulation refers to the process in which governments at all levels regulate, restrict and manage the behavior of coal enterprisesM\&A and the post-merger integration.M\&A environment includes institutional environment and market environment. The former is the relationship between enterprises and government.Government is the most important factor that determines the external environment of enterprises, and the interaction between its behavior and enterprise behavior directly affects the path of enterprise development.Coal enterprises will be affected by government regulations (industrial policies, laws and regulations, etc.) to a great extent in the development process, and even the specific economic behaviors within the enterprises

ISSN: 0010-8189

(C) CONVERTER 2021

www.converter-magazine.info 
will be interfered by government departments, or the introduction of relevant policies and regulations will make the whole industrial pattern change dramatically, thus affecting the competitive pattern of enterprises.Dissanaike(2020) pointed out that the government's supervision of mergers and acquisitions can reduce the utilization of market resources. Michael (2021) verified the negative impact of policy uncertainty on M\&A between Chinese and American companies [21]. The change of tax rate will also have an important impact on the frequency and quality of corporate acquisition [22].Therefore, coal enterprises must always pay attention to the changes of government regulation in the development process, make active use of policies that may promote the development of enterprises, actively adjust the original resource allocation and capacity requirements for new requirements, make major strategic changes, and take countermeasures to meet the external requirements of the government.

Resource integration includes two processes of resource identification and resource acquisition, focusing on the external implementation of the enterprise.Considering the importance of coal resources to ensure national energy supply and national economic and social development, governments at all levels have the right to distribute coal resources, because coal resources are owned by the state, and their development, use and integration must be carried out under the direct guidance or even direct control of national policies.The coal industry, as a resource-based enterprise community, is characterized by its dependence on resources. The government controls the strategic resources on which coal enterprises rely for their survival and development. As a planning director, public service provider, and supervisor, the government influences the direction of coal industry resource integration through industrial planning, industrial support, industrial transformation, infrastructure, support system construction, industrial development, and market order. Therefore, its resource integration process must be regulated and interfered by the government.Resource reconfiguration focuses on the combination and usage of resources within an enterprise, including resource allocation and resource utilization.Felipe (2021) believed that the process of resource allocation is a process of creating value from resources, a process of forming a unique ability of an enterprise, and a process of generating a unique competitive advantage for an enterprise [23].Resource reconfiguration can effectively enhance the resource flexibility and coordination flexibility of enterprises, which is beneficial for enterprises to integrate and reorganize different resources in different fields and apply them to the construction of enterprise competitiveness, turning potential opportunities into enterprise advantages, promoting product, technology, management and process innovation, quickly adapting to market demand and improving enterprise competitive performance [24]. The influence of the government on the resource reconfiguration of coal enterprises is mainly realized through industrial policies, safety production policies and environmental protection policies. For example, in view of the organizational reconstruction of coal enterprises, the government requires the coal production enterprises after the merger and acquisition to establish and perfect the safety production organization and put forward specific requirements for the relevant organizational setup;

Based on the above logic, the following hypotheses are put forward in this paper.

\section{H1a: Government regulation has a positive impact on the environmental perception of coal enterprises. H1b: Government regulation has a positive impact on resource integration of coal enterprises. H1c: Government regulation has a positive impact on resource reconfiguration of coal enterprises.}

\subsection{Industry competition and coal enterprise M\&A integration}

Industry competition refers to the intensity of competition among enterprises in the coal industry.Barnard (1998) believed that enterprise organization is a response to the external competitive environment.Environmental perception has three functions of insight cognitive function, opportunity recognition function and learning cognitive function, and five categories of objects: technological change perception, market demand perception, industry competition perception, enterprise crisis perception and policy and regulation perception, as well as stakeholders such as competitors, suppliers and partners of enterprises specific to the level of industry competition perception.Kayhan et al. (2020) believed that improving the perception ability of enterprises is helpful to understand the needs and preferences of customers, perceive changes in the external technological environment,

ISSN: 0010-8189

(C) CONVERTER 2021

www.converter-magazine.info 
detect competitive strategies of competitors, identify opportunities and threats, grasp the future development trend, and promote knowledge innovation and technological innovation [24].Enterprises should pay close attention to the changes of competitors, detect the changes of environment, eliminate adverse effects and adopt competitive strategies to ensure their dominant position in the competition. Agarwal et al. (2015) pointed out that the formation of new business will bring higher competitive pressure perception, while existing enterprises with small scale and low productivity and those located in densely populated areas are more likely to link new business formation with higher competitive pressure [25].

Coal enterprises, as enterprises engaged in resource exploitation, processing and utilization, are prone to decline and even die due to changes in external environmental factors such as resource depletion.The survival and development of coal enterprises mainly depend on the reserves and occurrence conditions of coal resources, and resource elements contribute the most to the development of coal industry [26].Because the coal industry has a completely competitive industrial structure, with a large number of enterprises, extremely low barriers to entry, and low requirements for technical capital and human resources, the key to enterprise development at this stage still depends on innate factors such as coal reserves owned by enterprises and occurrence conditions of resources, and resource elements contribute the most to enterprise development.Therefore, if coal enterprises want to gain an advantage in the competition, they must seize the right to exploit high-quality coal resources through resource integration, and must compete around the integration of high-quality coal natural resources, location conditions, industrial coordination conditions, capital resources and management resources, so as to obtain differential benefits brought by resource scarcity and quality differences. They must also optimize various resources through resource reconfiguration, so as to make all kinds of resources match and complement each other and gain competitive advantages.

Based on the above logic, the following hypotheses are put forward in this paper.

\section{H2a: Industry competition has a positive impact on environmental perception of coal enterprises. \\ H2b: Industry competition has a positive impact on resource integration of coal enterprises. \\ H2c: Industry competition has a positive impact on resource reconfiguration of coal enterprises.}

\subsection{Organizational alertness and coal enterprise M\&A integration}

Organizational alertness refers to the ability of coal enterprises to detect changes in internal and external environment, including four dimensions: multi-attention, interactive insight, forward-looking judgment and goal-leading, which is one of the key elements in the process of expanding research on entrepreneurial alertness and identifying and developing organizational entrepreneurial opportunities.In essence, organizational alertness is a key process and feature that characterizes the cognitive processing of environmental information by organizations, divided into three key processes, namely, attention insight (scanning), attention exertion (meaning generation or interpretation), and attention selection (learning and decision-making).Organizational alertness is an inherent feature of enterprises. In essence, it is dynamic observation and identification of the external environment, regardless of multi-attention, interactive insight or forward-looking judgment, aiming at improving the dynamic sensitivity of the enterprise environment and laying the foundation for resource integration and resource reconfiguration.

Alertness is a necessary prerequisite for enterprises to implement competitive behaviors. Chattopadhyay et al. (2011) found that enterprises must improve their ability to search, discover, identify, filter, understand and respond to changes in the external environment, dynamically optimize and allocate resources, and gain competitive advantages, because it is very important to keep alert to the external environment and implement organizational change actions[27].They also found that organizational alertness affects corporate decision-making preferences and resource input.Resource integration and resource reconfiguration are the most important action modes of organizational change in coal enterprises. Only on the basis of vigilance can coal enterprises grasp and make use of opportunities, evaluate the value of internal and external resources, change and reconstruct the existing resource

ISSN: 0010-8189

(C) CONVERTER 2021

www.converter-magazine.info 
structure, technical structure and knowledge structure, overcome the existing inertia of enterprises, realize the matching among all elements of enterprises, accumulate valuable resources and improve the competitiveness of enterprises.

Based on the above logic, the following hypotheses are put forward in this paper.

\section{H3a: Organizational alertness has a positive impact on environmental perception of coal enterprises. \\ H3b: Organizational alertness has a positive impact on resource integration of coal enterprises. \\ H3c: Organizational alertness has a positive impact on resource reconfiguration of coal enterprises.}

\subsection{Entrepreneurial orientation and coal enterprise M\&A integration}

Entrepreneurial orientation reflects the concept and mode of strategic decision-making of enterprise innovation, risk, and advanced action. At present, the three-dimensional view is generally accepted, that is, the three dimensions of innovation, initiative and risk taking [28]. Entrepreneurial orientation proposed in this paper refers to an attitude or willingness held by coal enterprises, which includes a series of process, practice and decision-making activities related to entrepreneurial behavior, such as opportunity identification and resource integration, to achieve the entrepreneurial goal of coal enterprises.Its innovative dimension refers to the willingness and degree of coal enterprises to create new products (or services) or improve existing products and services to meet the needs of the society, including the willingness and degree of using new technologies or new management methods and skills, and developing or strengthening products and services. Its proactive dimension refers to the willingness of coal enterprises to seize the development opportunities proactively and take proactive actions to proactively face the challenges brought by the external environment, so as to seize the opportunities of transformation and win new competitive advantages. Its risk dimension refers to the willingness of coal enterprises to invest a large amount of resources in high risk and high return projects, and is a measure of the risk taken by the coal enterprises and the tolerance of uncertainty. Because thecoal enterprises are faced with uncertain external environment, which has both market opportunities and varying degrees of risks, only those dare to take risks can seize the market opportunities and get higher enterprise performance.Chen et al. (2021) believed that entrepreneurship orientation affects organizational performance through the intermediary role of opportunity exploration ability and development ability [29].Therefore, it is necessary to explore, scan, search, perceive and detect the external environment of the organization, whether from the perspective of innovation dimension, antecedent dimension and risk-taking dimension, or from the antecedents and outcome variables of entrepreneurship orientation.

Entrepreneurship is a process of identifying opportunities, integrating resources and meeting customer needs.Enterprises need resources to pursue entrepreneurship, and the integration of resources is an important reason for transforming entrepreneurship orientation into enterprise performance. The input and integration of resources is the key to the effectiveness of entrepreneurship orientation and also the key to its function affecting enterprise performance.Resource reconfiguration is a process of resource allocation and utilization. Existing research indicates that there are many outcome variables in entrepreneurship orientation, such as social emotional wealth, business performance [14], business and political ties, resource utilization, dynamic capabilities, competitive advantages of new ventures, independent innovation, technological innovation, incremental innovation, breakthrough innovation. Entrepreneurial orientation affects enterprise performance through mediating or moderating variables such as market orientation, organizational learning, social capital, dynamic capability, absorptive capacity, opportunity exploration and development capacity, new enterprise capacity, social network, knowledge creation process, and knowledge capacity[6],[10],[11].Therefore, entrepreneurship orientation indirectly affects the process of enterprise resource integration and resource reconfiguration through direct relationship or as an intermediary variable.

Based on the above logic, the following hypotheses are put forward in this paper.

ISSN: 0010-8189

(C) CONVERTER 2021

www.converter-magazine.info 
H4a: Entrepreneurial orientation has a positive impact on environmental perception of coal enterprises.

H4b: Entrepreneurial orientation has a positive impact on resource integration of coal enterprises.

H4c: Entrepreneurial orientation has a positive impact on resource reconfiguration of coal enterprises.

\subsection{M\&A integration and coal enterprise performance}

Many studies have shown the importance of building enterprise capability through M\&A.Dynamic capability, as a high-level organizational capability, includes the perception of external opportunities and threats, the integration of internal and external resources and capabilities, and the separation and reconfiguration of resources, which are highly consistent with the key process of M\&A. Many studies have confirmed that M\&A is an entrepreneurial process within an enterprise organization, and successful M\&A is the process of building dynamic capability of an enterprise [4, 23].In this paper, the process of M\&A of coal enterprises is regarded as the process of building dynamic capabilities, and then the relationship between them and the performance of coal enterprises is studied. Among the studies on the outcome variables of dynamic capabilities, some studies have focused on the impact of dynamic capabilities on enterprise performanceand competitive advantage. Some scholars have studied the impact of dynamic capability on enterprise diversificationand entrepreneurial performance, management ability, ownership structure), technological innovation, entrepreneurship and entrepreneurship, capacity development and human capital.In this paper, it is believed that dynamic capability, as an organizational management capability, can adapt enterprises to the changing competitive environment by changing enterprise resource bases and developing new value creation strategies, and is the source of enterprises' sustained competitive advantage. Different dimensions of dynamic capability all affect enterprise performance.Because enterprise performance is a multi-dimensional structure, and the coal industry is a cyclical industry, the coal enterprise performance is divided into short-term performance and long-term performance in this study.

Based on the above logic, the following hypotheses are put forward in this paper.

H5a: Environmental perception has a positive impact on short-term performance of coal enterprises.

H5b: Environmental perception has a positive impact on the long-term performance of coal enterprises.

H6a: Resource integration has a positive impact on short-term performance of coal enterprises.

H6b: Resource integration has a positive impact on long-term performance of coal enterprises.

H7a: Resource reconfiguration has a positive impact on short-term performance of coal enterprises.

H7b: Resource reconfiguration has a positive impact on long-term performance of coal enterprises.

\section{Research Design}

\subsection{The measurement of research variables}

In this paper, the government regulation was measured with reference to the research of [8] and [10], the industry competition was measured with reference to the scale developed by [9], and the entrepreneurial orientation was measured with reference to the research of $[3,20]$, the organizational alertness was measured with reference to studies by [21], environmental perception was measured with reference to studies by [17], resource integration was measured with reference to studies by [18], and resource reconfiguration was measured with reference to studies by [5].Coal performance indicators were measured by combining short-term performance with long-term performance, with short-term performance measured by financial performance and long-term performance measured by competitive advantage.The above measurement items were scored by Likert 7-point scale, from "strongly disagree" to "strongly agree".

\subsection{Questionnaire design and data collection}

In this paper, the initial questionnaire was pre-tested, and about 40 valid questionnaire data were obtained by distributing the initial questionnaire to Poly Energy Holding Co., Ltd. and SDIC Coal Holding Co., Ltd. On this

ISSN: 0010-8189

(C) CONVERTER 2021

www.converter-magazine.info 
basis, the collected data were processed and simulated, and the expressions of related measurement items were revised to confirm that there was no semantic ambiguity in the questionnaire. The results of small-scale pre-test ruled out the problems of obvious answer tendency, too concentrated scores and biased questions. In the aspect of sample selection, the item "Has your enterprise merged and integrated the upstream and downstream enterprises related to coal in recent years" was added to the formal questionnaire to test whether the enterprise has conducted merger and integration, and those have not were excluded from the sample to ensure that the sample meets the research purpose.

The formal investigation began in December 2019. Through information channels such as China Coal Group, Poly Energy, China National Coal Association, Shandong Energy Group and social capital, the questionnaire was pushed through WeChat, QQ, e-mail, WJX. cn and other ways. Most of the sample enterprises surveyed were distributed in the major coal producing areas in China. Finally, 382 questionnaires were received in June 2020, with 323 valid, accounting for $84.5 \%$ of the total questionnaires recovered.In the study, the age of the enterprise, the size of the enterprise and the type of industry were taken as the control variables. From the age of the enterprise, $89.7 \%$ of the three types of enterprises in the sample are 8-15 years old, 20-40 years old and more than 40 years old. In terms of enterprise scale, enterprises with more than 10,000 employees accounted for $32.6 \%$ and enterprises with 500-1,000 employees accounted for 22.3\%.The sample involved six sub-sectors of coal industry, among which the cumulative percentage of coal mining industry, coal mine construction industry, coal machine equipment manufacturing industry and coal power industry was $85 \%$.

\section{Data Analysis and Results}

\subsection{Reliability and validity test of variables}

In this paper, the Corrected Item-Total Correlation (CITC) was used to reflect the reliability of variables, Cronbach's a coefficient was used to check the internal consistency of variables, and the modified CITC analysis was used to purify measurement items [29].Items with CITC value less than 0.30 or with $\alpha$ increased and overall reliability improved after deletion were deleted. The reliability of the measurement item was judged by the reliability coefficient of $\alpha$. The larger the value of $\alpha$ was, the higher the reliability would be. A threshold of 0.70 is generally accepted, with values greater than 0.50 [30].In this paper, the judgment principle of CITC in SPSS and $\alpha$ reliability coefficient were used to analyze each variable item one by one.The analysis results show that the CITC of each indicator of variable is more than 0.35, and the Cronbach $\alpha$ value is greater than 0.7 , which meets the requirements of reliability index. The reliability test is passed, indicating that the internal consistency of each variable measure is good.

In this paper, confirmatory factor analysis was used to verify the validity of variables.Generally speaking, the closer the value of $\chi 2 / \mathrm{df}$ is to 0 , the better the simulation between the sample data and the model, and the model with $\chi 2 / \mathrm{df}<5$ is generally acceptable [31].The larger the indicator values of NFI, IFI, and CFI, the better the fitting degree of the model and data. In general, the values of NFI, IFI, and CFI greater than 0.9 would be acceptable to the model. Values of NFI, IFI, and CFI greater than 0.95 indicate that the model and data have a good fit.Generally speaking, the smaller the RMSEA (root mean square error of approximation) index, the higher the fitting degree.RMSEA index is acceptable when it is between 0.05 and 0.08 , it indicates an average fitting degree between model and data when it is between 0.08 and 0.10 , and poor fitting degree when it exceeds 0.10 .In this paper, the fitting results of government regulation, industry competition, organizational vigilance, entrepreneurial orientation and other measurement models show that the values of $\chi 2, \chi 2 / \mathrm{df}$, NFI, TLI, CFI and IFI all meet the requirements, and each path coefficient has passed the significance test at the level of $\mathrm{p}<0.001$.

4.2 The relationship between descriptive statistics and variables

See Table 1 for the mean, variance and correlation coefficient of all variables.

ISSN: 0010-8189

(C) CONVERTER 2021

www.converter-magazine.info 


\subsection{Hypotheses testing}

In this paper, SPSS13.0 software and hierarchical linear regression technology were used to verify the relevant hypotheses, and the variables such as industry, enterprise age and enterprise scale were controlled in the regression model.The regression analysis results are shown in Table 2 to Table 5. The hierarchical regression results between coal enterprises' M\&A integration and enterprise performance are shown in Table 6.The results show that government regulation has a positive effect on environmental perception $(\beta=0.202, \mathrm{p}<0.01)$, and regression results support H1a; Government regulation has a positive impact on resource integration $(\beta=0.192$, $p<0.01)$, and regression results support $\mathrm{H} 1 \mathrm{~b}$; Government regulation has a positive effect on resource reconfiguration $(\beta=0.177$, $\mathrm{p}<0.01$ ), and regression results support H1c.Accordingly, the hierarchical regression results also support H2a, H2b, H2c, H3a, H3b, H3c, H4a, H4b, H4c, H5a, H5b, H6a, H6b, H7a and H7b.

In order to further verify the fitting degree between the conceptual model and the actual data, the structural equation model was used to verify the hypothesis test.According to the fitting results of the initial model, the covariance relationship between the increased residuals for the parameter paths with MI>3.84 was analyzed using the residuals output from the structural equation model [32], and the model was revised and determined for the initial model.After correction, the structural equation model shown in Fig. 1 is formed.Fitting was performed by importing data, and the results are shown in Table 7.The fitting results showed that the value of $\chi 2$ was 3380.516 ( $\mathrm{df}=1378$ ), and the value of $\chi 2 / \mathrm{df}$ was 2.453 , which was less than 3 ; RMSEA=.067, less than 0.08 ; The values of NFI, TLI, CFI, and IFI were $.916, .921, .901$, and .902, respectively, all higher than 0.9 , indicating that the model had a good fitting effect.There were a total of 18 paths between variables. Except for the paths of "resource integration <-government regulation" and "resource integration <-industry competition", the other paths were significant. These two paths passed the test in the hierarchical regression analysis, indicating that the hypotheses corresponding to the two paths were weakly supported.Other hypotheses were proved to be true by regression equation verification. After the model was structured, these hypotheses were further proved to be true by structural equation model verification, indicating that the relevant conclusions were robust.

Table 1 Descriptive statistics and correlation coefficient matrix of each variable

\begin{tabular}{|c|c|c|c|c|c|c|c|c|c|c|c|c|c|c|}
\hline & Variables & $\begin{array}{c}\mathrm{Me} \\
\text { an }\end{array}$ & $\begin{array}{l}\text { Vari } \\
\text { ance }\end{array}$ & 1 & 2 & 3 & 4 & 5 & 6 & 7 & 8 & 9 & 10 & $\begin{array}{l}1 \\
1 \\
\end{array}$ \\
\hline 1 & $\begin{array}{l}\text { Enterprise } \\
\text { age(EA) }\end{array}$ & $\begin{array}{c}3.0 \\
5\end{array}$ & 1.40 & 1 & & & & & & & & & & \\
\hline 2 & $\begin{array}{l}\text { Enterprise } \\
\text { scale(ES) }\end{array}$ & $\begin{array}{c}3.1 \\
6\end{array}$ & 1.57 & $\begin{array}{l}0.38 \\
4 * * *\end{array}$ & 1 & & & & & & & & & \\
\hline 3 & $\begin{array}{c}\text { Government } \\
\text { regulation }(\mathrm{GR})\end{array}$ & $\begin{array}{c}4.3 \\
6\end{array}$ & 1.35 & $\begin{array}{c}-0.01 \\
9\end{array}$ & $\begin{array}{c}-0.01 \\
3\end{array}$ & 1 & & & & & & & & \\
\hline 4 & $\begin{array}{c}\text { Industry } \\
\text { competition(IC) }\end{array}$ & $\begin{array}{c}5.0 \\
4\end{array}$ & 1.17 & $\begin{array}{l}0.17 \\
9 * * *\end{array}$ & $\begin{array}{c}0.01 \\
1\end{array}$ & $\begin{array}{l}0.45 \\
9 * * *\end{array}$ & 1 & & & & & & & \\
\hline 5 & $\begin{array}{l}\text { Organizational } \\
\text { alertness(OA) }\end{array}$ & $\begin{array}{c}5.0 \\
9\end{array}$ & 1.16 & $\begin{array}{c}0.05 \\
4\end{array}$ & $\begin{array}{c}0.04 \\
4\end{array}$ & $\begin{array}{l}0.18 \\
4 * * *\end{array}$ & $\begin{array}{l}0.47 \\
5 * * *\end{array}$ & 1 & & & & & & \\
\hline 6 & $\begin{array}{l}\text { Entrepreneurial } \\
\text { orientation(EO) }\end{array}$ & $\begin{array}{c}4.5 \\
1\end{array}$ & 1.27 & $\begin{array}{c}-0.05 \\
0\end{array}$ & $\begin{array}{c}-0.04 \\
0\end{array}$ & $\begin{array}{l}0.25 \\
4 * * *\end{array}$ & $\begin{array}{l}0.39 \\
5 * * *\end{array}$ & $\begin{array}{l}0.69 \\
5 * * *\end{array}$ & 1 & & & & & \\
\hline 7 & $\begin{array}{l}\text { Environmental } \\
\text { perception(EP) }\end{array}$ & $\begin{array}{c}4.7 \\
8\end{array}$ & 1.33 & $\begin{array}{c}-0.01 \\
4\end{array}$ & $\begin{array}{c}-0.02 \\
5\end{array}$ & $\begin{array}{l}0.19 \\
7 * * *\end{array}$ & $\begin{array}{l}0.36 \\
6 * * *\end{array}$ & $\begin{array}{l}0.71 \\
1 * * *\end{array}$ & $\begin{array}{l}0.81 \\
5 * * *\end{array}$ & 1 & & & & \\
\hline 8 & $\begin{array}{c}\text { Resources } \\
\text { integration(RI) }\end{array}$ & $\begin{array}{c}4.8 \\
7\end{array}$ & 1.27 & $\begin{array}{c}-0.00 \\
5\end{array}$ & $\begin{array}{c}-0.02 \\
7\end{array}$ & $\begin{array}{l}0.18 \\
3 * * *\end{array}$ & $\begin{array}{l}0.35 \\
0 * * *\end{array}$ & $\begin{array}{l}0.72 \\
7 * * *\end{array}$ & $\begin{array}{l}0.80 \\
5 * * *\end{array}$ & $\begin{array}{l}0.83 \\
7 * * *\end{array}$ & 1 & & & \\
\hline 9 & $\begin{array}{c}\text { Resource } \\
\text { reconfiguration } \\
\text { (RR) }\end{array}$ & $\begin{array}{c}4.7 \\
5\end{array}$ & 1.25 & $\begin{array}{c}-0.07 \\
3\end{array}$ & $\begin{array}{c}-0.09 \\
3^{*}\end{array}$ & $\begin{array}{l}0.20 \\
6^{* * *}\end{array}$ & $\begin{array}{l}0.33 \\
0 * * *\end{array}$ & $\begin{array}{l}0.71 \\
5 * * *\end{array}$ & $\begin{array}{l}0.80 \\
0 * * *\end{array}$ & $\begin{array}{l}0.80 \\
5 * * *\end{array}$ & $\begin{array}{l}0.84 \\
8 * * *\end{array}$ & 1 & & \\
\hline 10 & $\begin{array}{c}\text { Short-term } \\
\text { performance(S } \\
\text { TP) }\end{array}$ & $\begin{array}{c}4.4 \\
0\end{array}$ & 1.31 & $\begin{array}{l}-0.13 \\
1 * *\end{array}$ & $\begin{array}{l}-0.10 \\
5^{*}\end{array}$ & $\begin{array}{l}0.23 \\
9 * * *\end{array}$ & $\begin{array}{l}0.26 \\
4 * * *\end{array}$ & $\begin{array}{l}0.54 \\
3 * * *\end{array}$ & $\begin{array}{l}0.69 \\
7 * * *\end{array}$ & $\begin{array}{l}0.65 \\
3 * * *\end{array}$ & $\begin{array}{l}0.67 \\
8 * * *\end{array}$ & $\begin{array}{l}0.70 \\
3 * * *\end{array}$ & 1 & \\
\hline 11 & $\begin{array}{c}\text { Long-term } \\
\text { performance(L } \\
\text { TP) }\end{array}$ & $\begin{array}{c}4.6 \\
9\end{array}$ & 1.22 & $\begin{array}{c}-0.09 \\
8^{*}\end{array}$ & $\begin{array}{l}-0.11 \\
1 * *\end{array}$ & $\begin{array}{l}0.20 \\
0 * * *\end{array}$ & $\begin{array}{l}0.30 \\
5 * * *\end{array}$ & $\begin{array}{l}0.68 \\
2 * * *\end{array}$ & $\begin{array}{l}0.75 \\
2 * * *\end{array}$ & $\begin{array}{l}0.77 \\
4 * * *\end{array}$ & $\begin{array}{l}0.80 \\
4 * * *\end{array}$ & $\begin{array}{l}0.82 \\
0 * * *\end{array}$ & $\begin{array}{l}0.78 \\
0 * * *\end{array}$ & 1 \\
\hline
\end{tabular}

$* * * \mathrm{p}<0.01, * * \mathrm{p}<0.05, * \mathrm{p}<0.1$; Industry as a virtual variable is not listed in the correlation coefficient matrix. 
Table 2 Hierarchical regression results between government regulation and coal enterprise M\&A integration

\begin{tabular}{lccc}
\hline & $(2)$ & $(1)$ & $(3)$ \\
Variables & M1 & M3 & RI \\
\hline \multirow{2}{*}{ GR } & EP & RR & $0.177 * * *$ \\
& $0.202^{* * *}$ & $0.192 * * *$ & $(3.381)$ \\
EA & $(3.707)$ & $(3.753)$ & 0.027 \\
ES & -0.006 & -0.017 & $(0.450)$ \\
& $(-0.095)$ & $(-0.284)$ & -0.039 \\
Industry & -0.026 & -0.075 & $(-0.762)$ \\
Constant & $(-0.482)$ & $(-1.501)$ & Controlled \\
& Controlled & Controlled & $4.178 * * *$ \\
Observations & $3.990^{* * *}$ & $4.246 * * *$ & $(12.927)$ \\
R-squared & $(11.883)$ & $(13.458)$ & 323 \\
\hline
\end{tabular}

t-statistics in parentheses

$* * * \mathrm{p}<0.01, * * \mathrm{p}<0.05, * \mathrm{p}<0.1$

Table 3 Hierarchical regression results between industry competition and coal enterprise $M \& A$ integration

\begin{tabular}{lccc}
\hline & $(1)$ & $(2)$ & $(3)$ \\
Variables & M1 & M2 & R3 \\
\hline \multirow{2}{*}{ IC } & EP & RI & $0.402 * * *$ \\
& $0.439 * * *$ & $0.413 * * *$ & $(6.840)$ \\
EA & $(7.057)$ & $(6.902)$ & -0.057 \\
& -0.050 & -0.014 & $(-1.021)$ \\
ES & $(-0.845)$ & $(-0.255)$ & -0.075 \\
& -0.025 & -0.038 & $(-1.563)$ \\
Industry & $(-0.493)$ & $(-0.782)$ & Controlled \\
Constant & Controlled & Controlled & $3.280 * * *$ \\
& $2.898 * * *$ & $3.092 * * *$ & $(9.741)$ \\
Observations & $(8.124)$ & $(9.012)$ & 323 \\
R-squared & 323 & & 0.147
\end{tabular}

t-statistics in parentheses

$* * * \mathrm{p}<0.01, * * \mathrm{p}<0.05, * \mathrm{p}<0.1$

Table 4 Hierarchical regression results between organizational alertness and coal enterprise M\&A integration

\begin{tabular}{lccc}
\hline & $(1)$ & $(2)$ & $(3)$ \\
Variables & M1 & M2 & R3 \\
\hline OA & EP & RI & $0.789 * * *$ \\
& $0.817 * * *$ & $0.804 * * *$ & $(18.915)$ \\
EA & $(17.876)$ & $(18.837)$ & -0.056 \\
& -0.047 & -0.014 & $(-1.389)$ \\
ES & $(-1.060)$ & $(-0.330)$ & $-0.083 * *$ \\
& -0.034 & -0.047 & $(-2.378)$ \\
Industry & $(-0.889)$ & $(-1.308)$ & Controlled \\
Constant & Controlled & Controlled & $1.215 * * *$ \\
& $0.867 * * *$ & $1.008 * * *$ & $(4.783)$ \\
Observations & $(3.114)$ & $(3.880)$ & 323 \\
R-squared & 323 & 323 & 0.542 \\
\hline
\end{tabular}

ISSN: 0010-8189

(C) CONVERTER 2021

www.converter-magazine.info 
$\mathrm{t}$-statistics in parentheses

$* * * \mathrm{p}<0.01, * * \mathrm{p}<0.05, * \mathrm{p}<0.1$

Table 5 Hierarchical regression results between the three dimensions of entrepreneurship orientation and M\&A of coal enterprises

\begin{tabular}{|c|c|c|c|}
\hline & (1) & (2) & (3) \\
\hline & M1 & M2 & M3 \\
\hline Variables & $\mathrm{EP}$ & RI & $\mathrm{RR}$ \\
\hline Innovation & $\begin{array}{c}0.299 * * * \\
(6.568)\end{array}$ & $\begin{array}{c}0.309 * * * \\
(6.880)\end{array}$ & $\begin{array}{c}0.291 * * * \\
(6.571)\end{array}$ \\
\hline Risk & $\begin{array}{c}0.125 * * * \\
(2.619)\end{array}$ & $\begin{array}{c}0.194 * * * \\
(4.119)\end{array}$ & $\begin{array}{c}0.218 * * * \\
(4.703)\end{array}$ \\
\hline Proactiveness & $\begin{array}{c}0.423 * * * \\
(8.005)\end{array}$ & $\begin{array}{c}0.304 * * * \\
(5.834)\end{array}$ & $\begin{array}{c}0.281 * * * \\
(5.472)\end{array}$ \\
\hline EA & $\begin{array}{c}0.035 \\
(0.976)\end{array}$ & $\begin{array}{l}0.070 * \\
(1.962)\end{array}$ & $\begin{array}{c}0.027 \\
(0.762)\end{array}$ \\
\hline ES & $\begin{array}{c}-0.014 \\
(-0.441)\end{array}$ & $\begin{array}{c}-0.029 \\
(-0.943)\end{array}$ & $\begin{array}{c}-0.066 * * \\
(-2.167)\end{array}$ \\
\hline Industry & Controlled & Controlled & Controlled \\
\hline Constant & $\begin{array}{c}0.905 * * * \\
(4.390)\end{array}$ & $\begin{array}{c}1.183 * * * \\
(5.817)\end{array}$ & $\begin{array}{c}1.402 * * * \\
(6.993)\end{array}$ \\
\hline Observations & 323 & 323 & 323 \\
\hline R-squared & 0.680 & 0.660 & 0.658 \\
\hline
\end{tabular}

t-statistics in parentheses

$* * * \mathrm{p}<0.01, * * \mathrm{p}<0.05, * \mathrm{p}<0.1$

Table 6 Hierarchical regression results between M\&A of coal enterprises and enterprise performance

\begin{tabular}{|c|c|c|c|c|c|c|c|c|}
\hline Variables & $\begin{array}{c}\text { (1) } \\
\text { M1 } \\
\text { STP } \\
\end{array}$ & $\begin{array}{c}(2) \\
\text { M2 } \\
\text { LTP }\end{array}$ & $\begin{array}{l}\text { (3) } \\
\text { M3 } \\
\text { STP } \\
\end{array}$ & $\begin{array}{c}(4) \\
\text { M4 } \\
\text { LTP } \\
\end{array}$ & $\begin{array}{l}\text { (5) } \\
\text { M5 } \\
\text { STP } \\
\end{array}$ & $\begin{array}{c}\text { (6) } \\
\text { M6 } \\
\text { LTP } \\
\end{array}$ & $\begin{array}{c}\text { (7) } \\
\text { M7 } \\
\text { STP } \\
\end{array}$ & $\begin{array}{c}\text { (8) } \\
\text { M8 } \\
\text { LTP } \\
\end{array}$ \\
\hline EP & $\begin{array}{c}0.643 * * * \\
(15.907)\end{array}$ & $\begin{array}{c}0.709 * * * \\
(22.267)\end{array}$ & & & & & $\begin{array}{c}0.190 * * * \\
(2.620)\end{array}$ & $\begin{array}{c}0.203^{* * *} * \\
(3.912)\end{array}$ \\
\hline RI & & & $\begin{array}{c}0.689 * * * \\
(16.732)\end{array}$ & $\begin{array}{c}0.763 * * * \\
(24.343)\end{array}$ & & & $\begin{array}{c}0.224 * * * \\
(2.663)\end{array}$ & $\begin{array}{c}0.268 * * * \\
(4.460)\end{array}$ \\
\hline RR & & & & & $\begin{array}{c}0.717 * * * \\
(17.373)\end{array}$ & $\begin{array}{c}0.789 * * * \\
(25.305)\end{array}$ & $\begin{array}{c}0.359 * * * \\
(4.486)\end{array}$ & $\begin{array}{c}0.382 * * * \\
(6.694)\end{array}$ \\
\hline EA & $\begin{array}{c}-0.033 \\
(-0.727)\end{array}$ & $\begin{array}{c}0.000 \\
(0.000)\end{array}$ & $\begin{array}{c}-0.055 \\
(-1.248)\end{array}$ & $\begin{array}{c}-0.025 \\
(-0.732)\end{array}$ & $\begin{array}{c}-0.025 \\
(-0.570)\end{array}$ & $\begin{array}{c}0.009 \\
(0.274)\end{array}$ & $\begin{array}{c}-0.035 \\
(-0.846)\end{array}$ & $\begin{array}{c}-0.004 \\
(-0.121)\end{array}$ \\
\hline ES & $\begin{array}{l}-0.072 * \\
(-1.837)\end{array}$ & $\begin{array}{c}-0.074 * * \\
(-2.391)\end{array}$ & $\begin{array}{c}-0.062 \\
(-1.611)\end{array}$ & $\begin{array}{c}-0.062 * * \\
(-2.134)\end{array}$ & $\begin{array}{c}-0.034 \\
(-0.908)\end{array}$ & $\begin{array}{c}-0.032 \\
(-1.130)\end{array}$ & $\begin{array}{c}-0.047 \\
(-1.300)\end{array}$ & $\begin{array}{l}-0.047 * \\
(-1.805)\end{array}$ \\
\hline Industry & Controlled & Controlled & Controlled & Controlled & Controlled & Controlled & Controlled & Controlled \\
\hline Constant & $\begin{array}{c}1.808 * * * \\
(7.013)\end{array}$ & $\begin{array}{c}1.635 * * * \\
(8.051)\end{array}$ & $\begin{array}{c}1.530 * * * \\
(5.869)\end{array}$ & $\begin{array}{c}1.309 * * * \\
(6.586)\end{array}$ & $\begin{array}{c}1.294 * * * \\
(4.907)\end{array}$ & $\begin{array}{c}1.073 * * * \\
(5.379)\end{array}$ & $\begin{array}{c}1.076^{* * *} \\
(4.178)\end{array}$ & $\begin{array}{c}0.824 * * * \\
(4.480)\end{array}$ \\
\hline Observations & 323 & 323 & 323 & 323 & 323 & 323 & 323 & 323 \\
\hline R-squared & 0.480 & 0.628 & 0.503 & 0.668 & 0.521 & 0.684 & 0.559 & 0.741 \\
\hline
\end{tabular}

t-statistics in parentheses

$* * * \mathrm{p}<0.01, * * \mathrm{p}<0.05, * \mathrm{p}<0.1$

ISSN: 0010-8189 


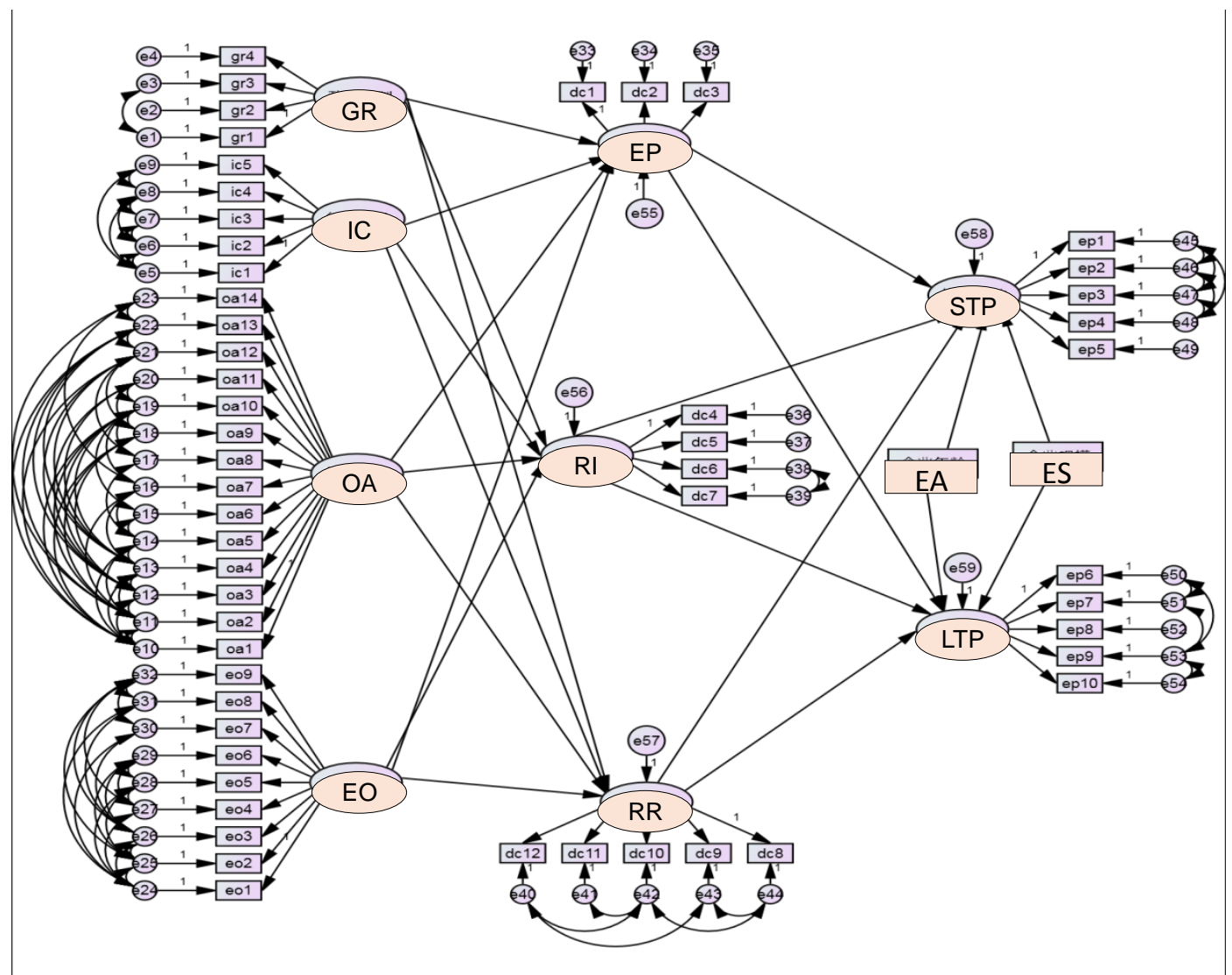

Fig 1: Path diagram of structural equation after correction

Table 7 Fitting results of modified structural equation model

\begin{tabular}{|c|c|c|c|c|c|}
\hline Variables<---Factors & $\begin{array}{l}\text { Standardized path } \\
\text { coefficient }\end{array}$ & $\begin{array}{l}\text { Path } \\
\text { coefficient }\end{array}$ & $\begin{array}{l}\text { Standard } \\
\text { error }\end{array}$ & $\begin{array}{l}\text { Critical ratio } \\
\text { (C.R.) }\end{array}$ & $\begin{array}{c}\text { Significance } \\
\mathrm{P}\end{array}$ \\
\hline EP<---GR & .301 & .401 & .050 & 8.020 & $* * *$ \\
\hline RI<---GR & -.032 & -.041 & .047 & -.865 & .057 \\
\hline RR<---GR & .462 & .531 & .046 & 11.543 & $* * *$ \\
\hline $\mathrm{EP}<---\mathrm{IC}$ & .131 & .081 & .016 & 5.061 & $* * *$ \\
\hline RI<---IC & .018 & .010 & .019 & .519 & .604 \\
\hline $\mathrm{RR}<---\mathrm{IC}$ & .302 & .151 & .029 & 5.207 & $* * *$ \\
\hline EP<---OA & .338 & .398 & .051 & 7.781 & $* * *$ \\
\hline $\mathrm{RI}<---\mathrm{OA}$ & .373 & .406 & .051 & 8.035 & $* * *$ \\
\hline $\mathrm{RR}<---\mathrm{OA}$ & .425 & .426 & .052 & 8.251 & $* * *$ \\
\hline EP<---EO & .828 & .728 & .052 & 13.979 & $* * *$ \\
\hline RI<---EO & .841 & .683 & .052 & 13.015 & $* * *$ \\
\hline RR<---EO & .765 & .570 & .047 & 12.068 & $* * *$ \\
\hline STP<---EP & .180 & .191 & .091 & 2.101 & .003 \\
\hline LTP<---EP & .192 & .213 & .072 & 2.958 & .004 \\
\hline STP<---RI & .319 & .354 & .118 & 3.006 & .003 \\
\hline LTP<---RI & .384 & .377 & .089 & 4.221 & $* * *$ \\
\hline STP<---RR & .317 & .384 & .112 & 3.434 & $* * *$ \\
\hline LTP<---RR & .436 & .468 & .087 & 5.382 & $* * *$ \\
\hline$\chi^{2} \quad$ df $\quad \chi^{2} / \mathrm{df}$ & NFI & TLI & CFI & IFI & RMSEA \\
\hline $\begin{array}{lll}3380.516 & 1378 & 2.453\end{array}$ & .916 & .921 & .901 & .902 & .067 \\
\hline
\end{tabular}

Note: $* * *$ in significance level means $\mathrm{p}<0.001$.

ISSN: 0010-8189

(C) CONVERTER 2021

Www.converter-magazine.info 


\section{Research Conclusions and Discussions}

5.1 Research conclusions and theoretical contributions

In this paper, based on 323 sample data of M\&A of coal enterprises in key coal-producing areas of the country, the influencing factors and mechanism of M\&A of coal enterprises are studied. The main theoretical contributions and innovations are as follows:

First of all, M\&A of coal enterprises is the result of a combination of various complicated factors.In this paper, according to the strategic cognitive theory, organizational change theory, dynamic capability theory, the government regulation, industry competition, organizational alertness, entrepreneurial orientation, dynamic capability and other related theories were firstly systematically sorted out and summarized on the basis of the scientific theoretical deduction and logical analysis, and enterprise M\&A integration cases in China Coal Group, Poly Energy, SDIC Coal, SDIC Xinji and other large coal enterprises were then interviewed in depth and studied, finally the four factors that affect coal enterprise M\&A were summarized: government regulation, industry competition, organizational alertness and entrepreneurial orientation.State-owned enterprises in the coal industry have become the guiding force for M\&A in the coal industry due to their large structural characteristics and the dual role of the government.In the coal industry, due to the characteristics of low industrial concentration, high competition intensity, obvious periodic fluctuation and fragility, industry competition, organizational alertness and entrepreneurial orientation have become important motivations to promote coal enterprises to implement M\&A.

Secondly, it constructs the conceptual model of influencing factors and mechanism of coal enterprise M\&A.Based on theoretical deduction, the relationship between coal enterprise M\&A influencing factors, capability building and enterprise performance was discussed from the perspective of dynamic capability, the transmission mechanism and influence path among variables were established, and the relationship model of coal enterprise M\&A influencing factors and action mechanism was constructed.Eighteen research propositions were put forward, each variable was defined operationally, and related measurement scales were designed. 323 sample data of coal enterprises in key coal-producing areas in China were collected by questionnaire method. The research hypotheses were examined empirically by hierarchical regression analysis and structural equation model, and the direct influence relationship and intermediary relationship between these variables were discussed.The study found that government regulation, industry competition, entrepreneurial orientation (three dimensions), and organizational alertness (four dimensions) had a significant positive impact on coal enterprise M\&A. Dynamic capability (three dimensions) had a positive impact on the performance of coal enterprises.By incorporating the four influencing factors into a structured model, the study found that government regulation and industry competition have a positive impact on environmental perception and resource reconfiguration, but the positive impact on resource integration is not significant, indicating the existence of negative effects of government regulation and industry competition. By applying the organizational alertness to mature enterprises, the realization mechanism of the impact of organizational alertness on the performance of coal enterprises was systematically discussed. The empirical data of the coal industry were used to verify the multidimensional structure of organizational alertness, entrepreneurial orientation and dynamic capabilities.

Thirdly, in this paper, the influence mechanism of coal enterprises' M\&A integration was chosen as the research object. Although some domestic scholars have studied the influencing factors and integration performance of coal enterprises from different angles, in previous studies, these dynamic factors were rarely considered as a whole, and the influence of these factors on coal enterprises' M\&A integration was seldom studied from the perspective of dynamic capability.The research points and perspectives of this paper are innovative.In addition, the related concepts such as organizational alertness, entrepreneurial orientation, and dynamic capability were applied to the M\&A integration of coal enterprises, which enriched the research perspective of M\&A integration of coal enterprises.In this paper, it is proposed that organizational alertness is a key element in the decision-making of coal enterprise M\&A, which is seldom in the previous studies. In this paper, it is an attempt to apply entrepreneurship theory to the research of coal enterprise M\&A integration. The related concepts of entrepreneurship orientation were mostly used in new ventures before, and extended to mature enterprises and incumbent enterprises, which

ISSN: 0010-8189

(C) CONVERTER 2021

Www.converter-magazine.info 
expanded the application scope of entrepreneurship theory research.M\&A integration process is regarded as the dynamic capability building process of coal enterprises, which is not found in previous studies.

\subsection{Research limitations and future research directions}

First of all, although 323 valid samples were collected through the use of various social capitals, the research based on a larger sample may be more representative and universal.The data collected in this paper are cross-sectional, which is slightly insufficient in judging the causal relationship between variables. In future research, panel data can be considered for longitudinal research.Finding appropriate second-hand data for empirical research and putting the existing sample enterprises in a longer period of time to examine is also one of the directions of future research.Most of the scales adopted in this paper come from mature research. In some scales, the differences between different industries and enterprises are not considered. Instead, a highly generalized scale is adopted based on the principle of seeking common ground while reserving differences. In the future, special scales should be developed through case studies or grounded theoretical research to better reflect the M\&A behavior of coal enterprises.

Secondly, in this paper, only the competition intensity, government regulation, entrepreneurial impulse, alertness behavior and other aspects faced by coal enterprises are considered in the study of the influencing factors and mechanism of coal enterprises' M\&A. In fact, the formation of decision-making behavior of coal enterprise M\&A is a multi-subject, multi-region and multi-time complex problem, which involves not only competition and interaction between coal enterprises, but also information feedback between enterprises and the market, game between government and enterprises, complexity and dynamics of the environment and many other factors.In the future research, the game theory can be introduced into the study of M\&A of coal enterprises to dynamically analyze the game process between enterprises and between enterprises and government.

Thirdly, for the convenience of research, the integration process after M\&A is treated as a "black box" in this paper, and the influence of interpersonal integration, task integration, procedural fairness and information fairness on enterprise performance is not considered in the empirical test process.In the future research, it is also one of the research directions to consider further study how to create value through effective integration and how to incorporate the uncertainty of the external environment into the research framework analysis.

\section{Acknowledgments}

First of all, the authors express special thanks for the anonymous reviewers' valuable suggestions. Their modification opinions make these research outcomes more perfect. Secondly, the research was supported by the National Social Science Fund of China [No. 20BGL185].

\section{References}

[1] Bi Naizhi. An Empirical Study on M\&A Performance and Government Intervention of Chinese Enterprises. Peking University, 2012.

[2] Pan Weier. Thoughts on Profit and Loss of Chinese Coal Industry Enterprises. Management World, 1996, (2): 106-113.

[3] Yang Jiachun, Guo Jun. Structure Orientation of Chinese Coal Market. Management World, 2000, (4): 85-91.

[4] Pan Kexi, Pu Jin, Xiang Tao. China Coal Market Concentration Based on a Comparative Analysis of Coal Market Concentration between China and the United States. Management World, 2002, (12): 77-88.

[5] Zhang Qing. Case Study on Value Chain Extension and Upgrade of Coal Enterprises. Management World, 2007, (4): 168-169.

[6] Song Yan, Ding Wenfen. Scale Economy in Merger and Reorganization of Chinese Coal Enterprises. China Coal, 2011, 37 (4): 32-35.

ISSN: 0010-8189

(C) CONVERTER 2021 
[7] Zhang Wenjing. Merger and Acquisition Performance Evaluation of Coal Enterprises under Supply-side Reform. Nanjing Normal University, 2018.

[8] Liang Lijun, Meng Fanchen. Improvement Mechanism of Knowledge Absorption Capacity in International M\&A of Enterprises. Science of Science and Management of S. \& T., 2011 (12): 71-78.

[9] Sun Ziyuan, Chen He, Lu Fangxu. Path Selection for Coal Resource Integration. Economic Review, 2012, (4): 89-92.

[10] Shi Jian. Mergers and Acquisitions of State-owned Enterprises and Government Behaviors. Xiamen University, 2002.

[11] Guo Rui. Positioning of Government Role in Mergers and Acquisitions of Chinese Enterprises. Renmin University of China, 2011.

[12] Leng Xinjia, Xie Shouxiang, Guo Junyi, Liang Xiaoshu, Li Xiang. Systematic Control of Interregional Integrated Coal Enterprises (Group). Journal of China University of Mining and Technology (Social Science Edition), 2011, 13 (4): 56-60.

[13] Zhu Xiumei, Chen Chen, Ji Yushan. Discussion on Competitive Advantage of New-Start Enterprises from the Perspective of Entrepreneurship Orientation, Networking Capability and Knowledge Resources. Foreign Economics \& Management, 2010 (5): 9-16.

[14] Andrzej Piosik, Ewa Genge. Earnings management prior to mergers and acquisitions: The role of acquirers' ownership structures. Evidence from Poland. Procedia Computer Science, 2020, 176: 1299-1311.

[15] Jennifer L. Blouin, Eliezer M. Fich, Edward M. Rice, Anh L. Tran. Corporate tax cuts, merger activity, and shareholder wealth. Journal of Accounting and Economics, 2021, 71(1): 101315.

[16] Niu Zhendong. Integration Synergy and Performance Evaluation of Coal Enterprises after Horizontal Merger and Acquisition. China University of Mining and Technology (Beijing), 2016.

[17] Tian Baoxin. Review and Evaluation of Merger and Restructuring Policy of Chinese Coal Enterprises. China Coal, 2016, 42 (11): 12-15.

[18] Zhang Yifei. Post-merger Integration Model of Enterprises Based on Core Competence. Beijing Jiaotong University, 2012.

[19] Li Yalei. Problems and Countermeasures of Merger and Acquisition Recombination of Coal Enterprises.Coal Economic Research, 2016(10): 26-29.

[20] Abebe, M.A., \& Angriawan, A. Organizational and competitive influences of exploration and exploitation activities in small firms. Journal of Business Research, 2014, 67(3): 339-345.

[21] Michael L. Katz. Big Tech mergers: Innovation, competition for the market, and the acquisition of emerging competitors. Information Economics and Policy, 2021, 54: 100883.

[22] Huijie Cui, Sidney Chi-Moon Leung. The long-run performance of acquiring firms in mergers and acquisitions: Does managerial ability matter?. Journal of Contemporary Accounting \& Economics, 2020, 16(1): 100185.

[23] Felipe Hernández-Perlines, Jeffrey G. Covin, Domingo E. Ribeiro-Soriano. Entrepreneurial orientation, concern for socioemotional wealth preservation, and family firm performance. Journal of Business Research, 2021, 126: 197-208.

[24] Kayhan Tajeddini, Emma Martin, Alisha Ali. Enhancing hospitality business performance: The role of entrepreneurial orientation and networking ties in a dynamic environment. International Journal of Hospitality Management, 2020, 90: 102605.

[25] Agarwal,R., Selen, W. Dynamic capability building in service value networks for achieving service innovation.Decision Science, 2015, 40(3): 431-475.

[26] Barnett, W. P. The dynamics of competitive intensity. Administrative Science Quarterly, 1997, 42(1): 128-160.

[27] Chattopadhyay, P.,Glick, W. H., Huber, G. P. Organizational actions in response to threats and opportunities. Academy of Management Journal, 2011, 44(5): 937-955.

[28] Jing A. Zhang, Conor O'Kane, Guoquan Chen. Business ties, political ties, and innovation performance in Chinese industrial firms: The role of entrepreneurial orientation and environmental dynamism. Journal of Business Research, 2020, 121: 254-267.

ISSN: 0010-8189

(C) CONVERTER 2021 
[29] Feiqiong Chen, Huiqian Liu, Yuhao Ge. How does integration affect industrial innovation through networks in technology-sourcing overseas M\&A? A comparison between China and the US. Journal of Business Research, 2021, 122: 281-292.

[30] Gishan Dissanaike, Wolfgang Drobetz, Paul P. Momtaz. Competition Policy and the Profitability of Corporate Acquisitions. Journal of Corporate Finance, 2020, 62: 101510.

[31] James Borthwick, Searat Ali, Xiaofei Pan. Does policy uncertainty influence mergers and acquisitions activities in China? A replication study. Pacific-Basin Finance Journal, 2020, 62: 101381.

[32] Javier Changoluisa, Michael Fritsch. New Business Formation and Incumbents' Perception of Competitive Pressure. Review of Industrial Organization, 2020, 56(1): 165-197. 